\title{
A QUESTION OF THE FUNCTION OF TRADITION IN ARTISTIC CREATION
}

\section{Safwat Nourel-Din}

My research explores the problem of tradition in relation to artistic creation, specifically as raised in the analyses of recently excavated ceramic artifacts on Failaka Island, Kuwait, and in interviews with contemporary art students, ceramicists, and art instructors in Crete, Athens, Cairo, Kuwait City, and Failaka Island. An artistic resolution is exhibited in five of my ceramic works.

Failaka, one of nine islands that are dependencies of the State of Kuwait, is located in the northwest portion of the Arabian Persian Gulf. It lies in the center of the entrance to Kuwait Bay, occupying a strategic position in relation to the State of Kuwait.

Several excavations in the last two decades revealed valuable evidence that linked Failaka to Dilmun, a civilization dated ca. 2800 B.C., and which was concurrent with those of Mesopotamia and the Inclus Valley. Other findings suggested the Greek, Selucid, and Parthian occupation of Failaka, brining forth its Hellenistic name, Icarus, given to the islands by Alexander the Great.

These findings pointed to Failaka as being a cultural, artistic, religious center and outpost in ancient times, outlining the honorable history and tradition of the country.

To further comprehend the ancient art and tradition of Failaka, examples of these artifacts were analyzed in terms of their forms, functions, and techniques. They included:

1. Two Hellenistic terracotta figures;

2. Examples of pottery representing both the Bronze Age and the Hellenistic settlement on the island;

3. Two Dilmun seals;

4. A Bronze Age kiln and a pottery workshop;

5. A study of five types of local clays.

The study revealed the exceptional, if simple, beauty of the art of Failaka.

Naturally, influence of such art would be expected to appear in modern ceramic works in Kuwait. However, extensive interviews with Kuwaiti artists and educators revealed that modern ceramic works were created primarily in public schools rather than in professional artists' studios. These interviews also pointed to the sad fact that no Kuwaiti ceramic works, either inside or outside the country, have been exhibited lately. Therefore, I had to modify the study of contemporary Kuwaiti ceramics to include only those produced in the schools that were, according to the Art Education Department, offering the best public school ceramic programs in Kuwait. Interviews with students and art teachers of seven selected schools, and a review of their ceramic works, 
revealed the striking lack of knowledge and awareness of the students about their ancient art. The modern woris attested to the undoubted discontinuity of tradition. However, the naivete and awkwardness of these works did not exclude the creative essence of these young, talented students. So there was creativity but no tradition.

Tradition is a term used here to mean the knowledge or influence of the past on present life-particularly in the arts. A question begging an answer is, "To what extent should tradition be involved in modern 'art' or 'life' without corrupting creativity and inventiveness. To answer this question, it was necessary to study modern ceramics and trace traditional influence on them. However, modern Kuwaiti ceramics proved the certain discontinuity of tradition, as mentioned earlier. Therefore, I had to seek the answer to the question elsewhere than Kuwait. Trips to several ceramic workshops, particularly in places where people preferred to hold onto their tradition, such as Eghaleo, Athens; Thrapsano, Crete; Fustat, Cairo, Egypt; and Failaka, Kuwait were undertaken in order to study the relationship between traditional knowledge and modern works of pottery. The study, and the interviews, proved that the application of traditional methods varied from one place to another; consequently, the result of the new product varied as well, and could be analyzed as follows:

The discontinuity of tradition - when traditional knowledge is unknown for some reason and, therefore, the modern process has absolutely no link with the past, such as that in the modern schools in Kuwait.

The abandonment of tradition - when traditional knowledge is not included any longer with the new sophistication and modernism of a specific culture.

The continuity of tradition -- when the new work is a replica of practices in ancient times. The result is nothing but routine reiteration -- perhaps the greatest opposition to creativity.

The corrupting of tradition - when traditional knowledge is used as a means of making money rather than creating works of art. The result is a debilitated work that does not involve any creative thought or innovation; neither was proper in introducing the great ancient art.

The main goal of this study was to find the appropriate way of using traditional knowledge to produce creative ceramic works, and then follow this way in producing creative modern works of ceramics in Kuwait. Apparently, none of the applications of traditional methods examined earlier succeeded in producing works of art and, therefore, none was appropriate to be followed.

It has long been argued that tradition hinders creativity, but some philosophers disagree with this argument. In his book, Tradition, Edward Shils indicates that for tradition to be fruitful and not fatal, traditional knowledge should be accepted as the beginning or guideline for new ideas and new work. The new work, suggests Shils, may be similar to the tradi- 
tional one in some respect, but should contain an element of significant novelty (Shils, 1981, p. 214). In Art and Illusion, Gombrich refers to the key phrases in his formula of viewing the work of art as the growth through tradition and skill (Gombrich, 1979, p. 27). J. Dewey cites the importance of tradition forming a large part of one's background. He indicates that the dependence on tradition and the appropriate training in the skills of the art form are both essential elements in the creative process (J. Dewey, 1934, p. 265).

The "formula" of growth through tradition -- expansion or advancement of tradition -- seems to be the most appropriate for producing creative works of art in Kuwait, an art that can stand firmly fixed in the current art world and thus be internationally appreciated, yet which has roots that echo the great past of Failaka and its aesthetic values. Such a formula is more suitable for an Arab country like Kuwait, a country that strongly holds onto its tradition and, at the same time, is open to creative ideas and innovation.

Therefore, l've chosen that my ceramic works, proposed for this research, focus on the advancement of tradition in a formula that links and fuses tradition, skill, and creativity. This work should be regarded as merely a suggested prescription for applying traditional methods and ideas in creating works of art. These ceramic forms are:

Insight, a folded letter, an envelope, a pair of eye-glasses, and the space around the forms combined into a sculpture. Photo-ceramic technique is employed for the stamp on the envelope. The writing on the letter recalls the traditional function of writing on clay. The idea itself -- the insight - is an allegory for handing-down experience from the old generation to the new.

No More is a slab of porcelain that bears a poem on one half of its surface and several photo-ceramic images which have been cut and assembled as a collage, forming a composition on the other half. This assemblage brings to mind the ancient function of combining plastic art and works of literature, especially as in the lines of cuneiform found on ceramic bowls, the inscriptions that appear on most of the Mesopotamian cylinder seals, the Egyptian hieroglyphs on most ancient Egyptian art, etc.

Tradition is a structure objectifying a semi-rectangular house in an Islamic style, blended with Indian and Chinese. The inside of the back wall bears a photo-ceramic image of a gloomy ivoman in traditional dress. This form conveys the negative side of the term "tradition," and demonstrates the danger of its misuse which can lead to self-imprisonment and isolation, thereby never being able to look forward, to develop or create.

Tribute to Failaka represents a vessel in a half-egg-shape made out of a series of coils, recalling the ancient form of the Red Ridged Pottery found on Failaka. It is salt-glazed to accentuate the linear quality of the coiled ridges by emphasizing the difference in color shading, because salt normally does not collect on the sharper edges of the ware.

The Cycle -- the ancient half-sphere form (globular), and the Draped Female Figurine were the inspiration for creating this form. It is a huge globe, the lower half of which is ceramic and the upper half acrylic (plexiglas). A set 
of figurines of graduated sizes are standing in a "C"-curved line in half of the lower portion of the glove, while photo-ceramic images of these figurines are lined in a reverse "C"-line on the other half of this portion. Together the figurines and their reverse images form an "S" line that is a reminder of the ousborous, "the ancient symbol of the snake biting its own tail signifying the eternal cycle of life" (Guerin, 1979, p. 159). This form symbolizes the world and its paradoxes: the seen, touched, and unseen; earth, dust, sin, materiality, and the transparent, the spiritual, holiness, heaven. It is imperative, however, for the continuance of the cycle that they remain together, paradoxical though that may be.

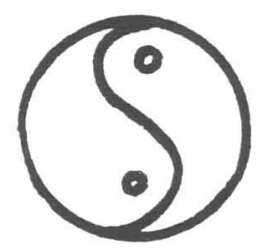

As mentioned above, the formula introduced in this study and the suggested application of specific traditional elements in modern works of art were only my choice. Each individual should choose those different elements of his past that he finds will fit into his creative, contemporary art, and which are appropriate for the present needs of his culture.

In conclusion, I would like to quote from W. H. Auden:

Though their particulars are those that each particular artist knows, Unique events that once took place Within a unique time and space, In the new field they occupy

Becomes, though still particular, An algebraic formula, An abstract model of events Derived from dead experiments And each life must itself decide To what and how it be applied.

(W. H. Auden, Gombrich, 1972, p. 146).

\section{REFERENCES}

Shils, E. Tradition. Chicago: University of Chicago Press, 1981.

Gombrich, E.H. Art and Illusion. Bollingen Series xxxv, 5. New Jersey: Princeton University Press, 1972.

Dewey, J. Art as Experience. New York: G. P. Putnam's Sons, 1934; Capricorn Books, 1958.

Auden, W. H. "The New Year Letter, 1940," from Gombrich, E. H., Art and Illusion. Bollingen Series $x \times x v, 5$. New Jersey: Princeton University Press, 1972. 